\title{
Optimization of Nickel and Copper Ions Removal by Modified Mangrove Barks
}

\author{
Rozaini C. A., Jain K., Oo C. W. Tan K. W., Tan L. S, Azraa A. and Tong K. S.
}

\begin{abstract}
Mangrove barks Rhizophora apiculata which have been chemically modified in basic condition were used as adsorbent for the removal of nickel and copper ions from aqueous solution. The adsorbent was characterized by SEM images, FT-IR and BET analysis. Effecting parameters like initial $\mathrm{pH}$, initial concentrations of metal ions and contact time were investigated. The adsorption data were well fitted by Freundlich isotherm model. Kinetic data were best described by pseudo-second-order model. Thermodynamic studies showed spontaneous and exothermic nature in the adsorption of $\mathrm{Ni}(\mathrm{II})$ and $\mathrm{Cu}$ (II) ions by the modified mangrove barks.
\end{abstract}

Index Adsorption, Copper, Nickel, Rhizophora apiculata.

\section{INTRODUCTION}

The amount of heavy metal ions released to the environment has been increasing significantly resulting from industrial activities and technology development. Heavy metal ions present in wastewaters and released by various industries such as mining, electroplating, electronic equipment, and battery manufacturing processes. The wastewater commonly contains $\mathrm{Cu}, \mathrm{Ni}, \mathrm{Cd}, \mathrm{Cr}$, and $\mathrm{Pb}$ which are not biodegradable and their accumulation in ecological system can cause harmful effects to human, animals and plants. The excessive exposure to nickel can lead to severe damage of lungs, kidneys, skin dermatitis, and cancer [1]. Copper consumption in high doses can cause serious toxicological concerns since it can be deposited in the brain, skin, liver and pancreas. It will then lead to nausea, vomiting, headache, diarrhea, respiratory difficulties, liver and kidney failure, and death [2]. As a result, various studies have been conducted for the removal of heavy metal ions in wastewaters.

Common techniques used to remove heavy metal ions from industrial wastewater have been reported in literature which includes ion-exchange, reverse-osmosis, electro-coagulation, chemical precipitation, neutralization, and adsorption [3]. Recently, adsorption has attracted considerable interest especially from cheap and abundantly available agriculture waste material. Different types of agriculture wastes such as maize tassel [4], banana peel [5], saw dust and neem bark [6], wheat straw, soybean straw, corn cobs and corn stalks [7] and Pinus sylvestris sawdust [8] have been studied for the

Rozaini C. A., Jain K., Oo C. W., Tan K. W. are from School of Chemical Sciences, Universiti Sains Malaysia, Penang 11800, Malaysia. (Tel: +604-6574854; e-mail: rozaini.07@gmail.com) removal of heavy metal ions. However, the capacity is low compared to commercially available ion exchange resins or activated carbon, but modifications (base, acid, and heat treatment) have shown improvement in the adsorption capacity for these agricultural by-products [9] producing higher value product with potentially lower cost as compared to the commercially available adsorbents.

Following this approaches, this paper discusses the use of mangrove barks for the adsorption of heavy metal ions from simulated aqueous solutions. Mangrove bark is an agricultural waste from the debarking process of mangrove logs in the charcoal making industry. Accumulation of the waste barks from this industry had resulted in the occupation of land space and contamination of ground and estuaries water. The chemical composition of bark is complex and varies between and within species, and also between the inner and outer bark. Generally, chemical analysis of bark from different species indicates that bark can be classified into four major groups: polysaccharides, lignin and polyphenols, hydroxy acid complexes, and extractives [10]. All these materials have capacity for binding metal cations due to hydroxyl, carboxylic and phenolic groups present in their structure. These barks are inexpensive, abundant, and contain polyphenolic compounds that under appropriate conditions of $\mathrm{pH}$ and temperature are capable of adsorbing significant quantities of metal cations from solution [11]. At present, these barks are left dried and burnt in order to clear the working land space. Hence, the conversion of these waste barks to value-added adsorbents for waste water treatment would not only be economical, but also help to solve waste disposal and reduce air pollution. The main objective of this study was to investigate the feasibility of using the chemically modified mangrove bark (MBB) for the removal of $\mathrm{Ni}(\mathrm{II})$ and $\mathrm{Cu}(\mathrm{II})$ ions from aqueous solutions.

\section{MATERIALS AND METHODS}

\section{A. Adsorbate}

The stock solutions of $\mathrm{Ni}(\mathrm{II})$ and $\mathrm{Cu}(\mathrm{II})$ ions used in this study (1000 $\mathrm{m} \mathrm{L}^{-1}$ ) were prepared by dissolving weighed quantities of $\mathrm{NiSO}_{4} \cdot 6 \mathrm{H}_{2} \mathrm{O}$ and $\mathrm{CuSO}_{4} .5 \mathrm{H}_{2} 0$ salt in distilled water. Experimental solutions with the desired concentrations were prepared by diluting the stock solution with distilled water.

\section{B. Preparation of Adsorbent}

Mangrove barks (Rhizophora apiculata), a waste of local 
charcoal factory collected from Matang mangrove forest, were washed repeatedly to remove dust and soluble impurities. The barks were then dried in sunlight and ground to a fine powder with $250 \mu \mathrm{m}$ mesh. For modification process, the bark powder was treated with $37 \%$ formaldehyde and 0.1 $\mathrm{M} \mathrm{NaOH}$ at $50{ }^{\circ} \mathrm{C}$ for $2 \mathrm{~h}$. The barks were filtered out, washed with distilled water until the washings were approximately at $\mathrm{pH} \mathrm{4}$, and oven dried. The modified bark (MBB) was kept in an airtight container for further use.

\section{Characterization and Adsorption Studies}

Characterization of the adsorbents was carried out by scanning electron microscope (SEM), surface area analysis, and FT-IR studies. Scanning electron microscopic (Leo Supra 50VP) studies was conducted to observe the surface texture and porosity of the adsorbents. The surface area of the adsorbent was measured by BET (Brunauer-Emmett-Teller nitrogen adsorption technique). FT-IR (Perkin Elmer 2000 FTIR) spectrometer was employed to determine the type of functional groups in mangrove barks responsible for metal adsorption.

The adsorption experiments were conducted batch wise. A weighed amount of adsorbents and $50 \mathrm{~mL}$ of aqueous solution containing the metal ion was shaken on an orbital shaker at room temperature. The effect of the initial $\mathrm{pH}$ on heavy metal ion removal was studied by performing equilibrium adsorption tests at different $\mathrm{pH}$ values. The adsorption isotherms of $\mathrm{Ni}(\mathrm{II})$ and $\mathrm{Cu}$ (II) ions on the adsorbent were studied at concentration $10-100 \mathrm{mg} \mathrm{L}^{-1}$. The adsorption kinetic studies were carried out under optimized conditions from 2 to $180 \mathrm{~min}$. The mixture was filtered and the concentration of the remaining metal ion in the filtrate was determined by the atomic absorption spectrophotometer (Perkin Elmer AAnalyst 200). Amount of metal ion uptake by $1 \mathrm{~g}$ of the adsorbent was calculated from the following mass balance equation:

$$
q_{e}=\frac{\left(C_{O}-C_{e}\right) V}{M}
$$

where $q_{e}\left(\mathrm{mg} \mathrm{g}^{-1}\right)$ is the amount of metal ion uptake, $C_{\mathrm{e}}(\mathrm{mg}$ $\left.\mathrm{L}^{-1}\right)$ the metal ion concentration after adsorption, $C_{\mathrm{o}}\left(\mathrm{mg} \mathrm{L}^{-1}\right)$ the initial metal ion concentration, $M$ the amount of adsorbent (g) and $V$ the volume of solution (L). Percent removal was also evaluated using the formula:

$$
\operatorname{Removal}(\%)=\frac{\mathrm{C}_{\mathrm{O}}-\mathrm{C}_{\mathrm{e}}}{\mathrm{C}_{\mathrm{O}}} \times 100
$$

\section{RESULTS AND DisCUSSION}

\section{A. Characterisation of Adsorbent}

The SEM was used to observe the changes in the surface morphology of the materials. SEM images of unmodified bark and MBB were shown in Fig. 1. The adsorbent have irregular structure, thus makes possible for the adsorption of heavy metal ions on different parts of the adsorbent. The figures illustrate the surface texture and porosity of bark adsorbent with holes and small openings on the surface which increased the contact area. These will lead to pores diffusions during adsorption [12]. Morphological analysis of the raw bark and modified bark showed changes of loose bark into more compact form of adsorbent.

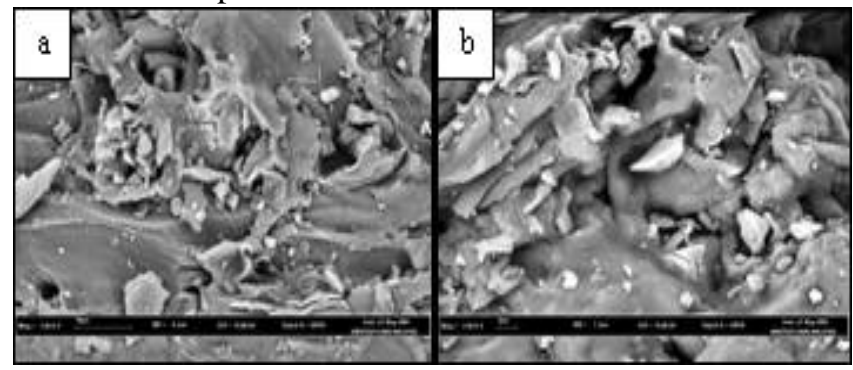

Fig. 1: SEM Image of unmodified bark (a) and MBB (b).

Surface area is related to the adsorption capacity of an adsorbent. As the surface area increases, more binding sites are available for the adsorbate to be adsorbed [13]. The multipoint BET surface area analysis of MBB was performed with Quantachrome Nova 2200e. The surface area of MBB was found to be $3.453 \mathrm{~m}^{2} \mathrm{~g}^{-1}$. The surface area was higher, compared to other adsorbents like rubber leaf powder $(0.478$ $\left.\mathrm{m}^{2} \mathrm{~g}^{-1}\right)$ [14], quebracho tannin $\left(0.820 \mathrm{~m}^{2} \mathrm{~g}^{-1}\right)$ [15] and mangrove tannin $\left(1.67 \mathrm{~m}^{2} \mathrm{~g}^{-1}\right)$ [16]. Possibly the high sorption capacity of MBB observed in this study despite its low surface area could be attributed to both chemical and physical adsorption processes which most likely occurred on its surface.

Table 1: Textural Properties of MBB

\begin{tabular}{lc}
\hline Characterization & MBB \\
\hline Surface area $(\mathrm{BET}), \mathrm{m}^{2} \mathrm{~g}^{-1}$ & 3.453 \\
Micropore area, $\mathrm{m}^{2} \mathrm{~g}^{-1}$ & 0.00 \\
Mesopore area, $\mathrm{m}^{2} \mathrm{~g}^{-1}$ & 3.453 \\
Total pore volume, $\mathrm{cm}^{3} \mathrm{~g}^{-1}$ & $7.439 \mathrm{e}-2$ \\
Micropore volume, $\mathrm{cm}^{3} \mathrm{~g}^{-1}$ & 0.000 \\
Mesopore volume, $\mathrm{cm}^{3} \mathrm{~g}^{-1}$ & $8.504 \mathrm{e}-2$ \\
Average pore diameter (BET) $\AA$ & 86.170 \\
$\mathrm{BJH}$ adsorption average pore diameter, $\AA$ & 247.10 \\
$\mathrm{pH}_{\mathrm{zpc}}$ & 5.20 \\
\hline
\end{tabular}

The FTIR technique is an important tool to identify the characteristic functional groups on the adsorbent surface. The spectrum of $\mathrm{MBB}$ revealed the presence of a strong band in the region of $4000-3000 \mathrm{~cm}^{-1}$, associated with -OH group. Small peak in the vicinity of $2800-3060 \mathrm{~cm}^{-1}$ is assigned to the $-\mathrm{CH}$ - stretching and the $-\mathrm{CH}_{2}$ - bridges formed by the reaction between mangrove bark and formaldehyde. Peaks at the region of $740-910 \mathrm{~cm}^{-1}$ can be assigned to the deformation vibrations at $\mathrm{C}-\mathrm{H}$ bond in the phenolic rings. Peaks in the vicinity of $1650-1450 \mathrm{~cm}^{-1}$ showed the presence of aromatic rings. The signal at $1452 \mathrm{~cm}^{-1}$ shows the present of $-\mathrm{CH}_{2-}$. The peaks at 1317 and $1040 \mathrm{~cm}^{-1}$ in the spectrum are due to $-\mathrm{OH}$ - bending belongs to phenol group. When comparing the FTIR spectra of MBB and fresh bark, FTIR spectrum of MBB showed simplicity of the peaks at the vicinity of $740-910 \mathrm{~cm}^{-1}$. The MBB spectra also showed the collapsed of peak at $1110 \mathrm{~cm}^{-1}$ as a shoulder indicating that polymerization had occurred. 


\section{B. Effect of $p H$}

The effect of $\mathrm{pH}$ on the adsorption of $\mathrm{Ni}$ (II) and $\mathrm{Cu}$ (II) ions were carried out over the $\mathrm{pH}$ range of 2 to 10, while keeping all other parameters constant. Adsorption was found increased with the increasing of $\mathrm{pH}$. This phenomenon could be explained by increasing total net negative charges of surface adsorbent which intensified electrostatic forces in the adsorption process. Moreover with increasing $\mathrm{pH}$, total number of negative groups available for the binding of metal ions increased and therefore competition between proton and metal ions became less pronounced [18]. Result showed that the MBB possessed optimum sorption capacity for both $\mathrm{Ni}$ (II) and $\mathrm{Cu}$ (II) ions at $\mathrm{pH} 5$ (Fig. 2). At lower $\mathrm{pH}$ than 8, the dominant forms of nickel was $\mathrm{Ni}^{2+}$; while at $\mathrm{pH}$ more than 8 , $\mathrm{Ni}(\mathrm{OH})_{2}$ were present as precipitate [19]. Whereas $\mathrm{Cu}(\mathrm{OH})_{2}$ will be the dominant species at $\mathrm{pH}$ more than $\mathrm{pH} 6$ [20].

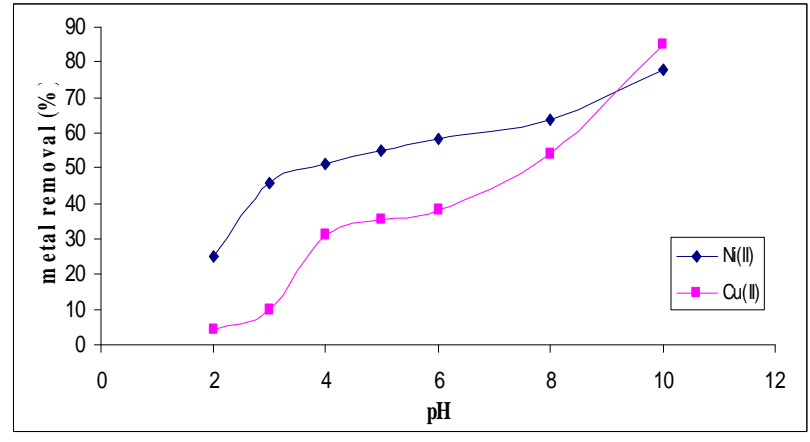

Fig. 2: Effect of initial $\mathrm{pH}$ on the adsorption of $\mathrm{Ni}(\mathrm{II})$ and $\mathrm{Cu}(\mathrm{II})$ on $\mathrm{MBB}$.

\section{Effect of Adsorbent Dosage}

Adsorbent dosage seemed to have great effect on adsorption process. The result of the effect of MBA dosage showed that removal efficiency increased as the adsorbent dosage increased (Fig. 3). For $10 \mathrm{mg} \mathrm{L}^{-1}$, adsorption percentage increased when the adsorbent dosage increased from 0.1 to $3.0 \mathrm{~g}$ at $\mathrm{pH}$ 5. The critical value of dosage of $\mathrm{MBB}$ was $1.0 \mathrm{~g}$ for both $\mathrm{Ni}(\mathrm{II})$ and $\mathrm{Cu}(\mathrm{II})$ ions. Increasing the amount of adsorbent added into a fixed concentration ions solution will increase the availability of active sites of the adsorbent. Therefore, adsorption percentage and efficiency will also increase [21].

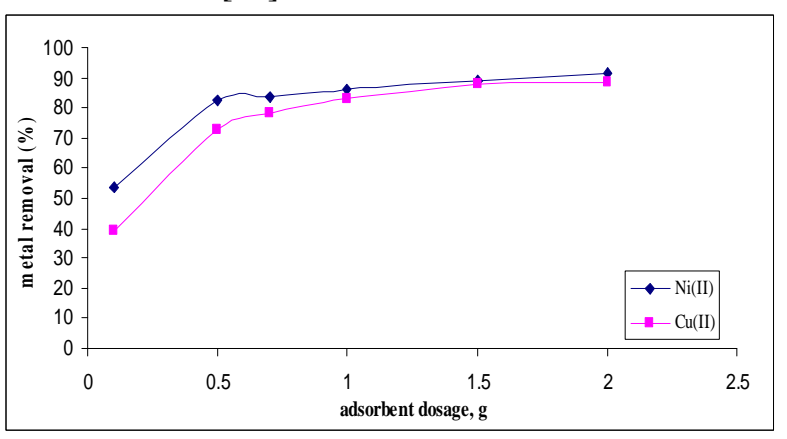

Fig. 3: Effect of adsorbent dosage on the adsorption of $\mathrm{Ni}(\mathrm{II})$ and $\mathrm{Cu}(\mathrm{II})$ on MBB.

\section{Adsorption Isotherms}

The adsorption of $\mathrm{Ni}(\mathrm{II})$ and $\mathrm{Cu}(\mathrm{II})$ ions were also investigated as a function of concentration in the range of 10 - $100 \mathrm{mg} \mathrm{L}^{-1}$ using $1.0 \mathrm{~g}$ of adsorbent, $50 \mathrm{~mL}$ of adsorbate solution at $\mathrm{pH}$ 5. Initial concentration provides the necessary driving force to overcome resistance of mass transfer between heavy metal ions in the aqueous phase and adsorbents [22]. Adsorption efficiency decreased with the increment of initial heavy metal ion concentration (Fig. 4).

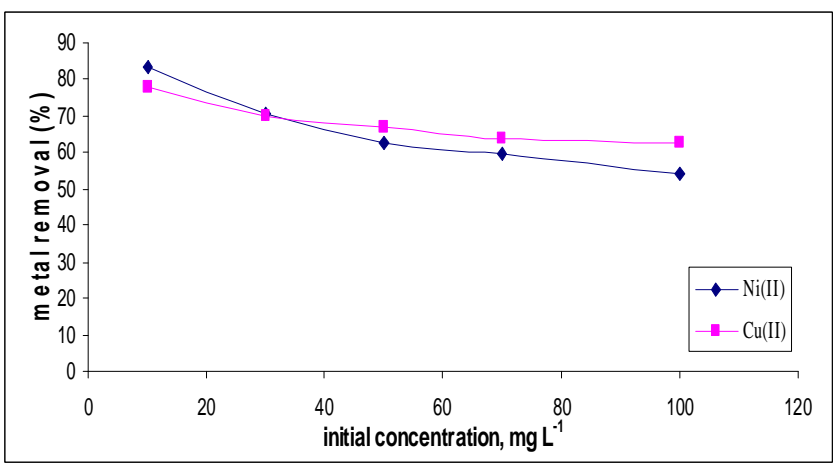

Fig. 4: Effect of initial concentration on the adsorption of $\mathrm{Ni}(\mathrm{II})$ and $\mathrm{Cu}(\mathrm{II})$ on $\mathrm{MBB}$

The experimental equilibrium data obtained were fitted with Langmuir and Freundlich isotherm models. Langmuir isotherm describes monolayer adsorption based on the assumption that all the adsorption sites have equal adsorbate affinity and that adsorption at one site does not affect adsorption at an adjacent site [23]. The Langmuir isotherm is given as below:

$\frac{C_{e}}{q_{e}}=\frac{1}{q_{\max } b}+\frac{C_{e}}{q_{\max }}$

where $C_{e}$ is the equilibrium concentration $\left(\mathrm{mg} \mathrm{L}^{-1}\right), q_{e}$ is the amount adsorbed at equilibrium $\left(\mathrm{mg} \mathrm{g}^{-1}\right), q_{\max }$ is the monolayer adsorption capacity $\left(\mathrm{mg} \mathrm{g}^{-1}\right)$ and $b$ is the Langmuir equilibrium constant $\left(\mathrm{L} \mathrm{mg}^{-1}\right)$. Meanwhile, Freundlich isotherm equation considers heterogeneous surfaces and is based on the idea that the adsorption depends on the energy of the adsorption sites [24]. Freundlich isotherm can be written as:

$\log q_{e}=\log K_{F}+\frac{1}{n} \log C_{e}$

where $K_{F}$ is the Freundlich constant and $1 / n$ is the heterogeneity factor.

The Langmuir and Freundlich isotherm constants were given in Table 2. Correlation coefficient $\left(\mathrm{R}^{2}\right)$ of the adsorption isotherm data showed that adsorption of $\mathrm{Ni}$ (II) and $\mathrm{Cu}$ (II) ions on MBB were better fitted to Freundlich isotherm model (Fig. 5). The $1 / n$ value which was in between 0.1 and 1.0 confirmed the heterogeneity of the adsorbent and it indicates that the bond between heavy metal ion and MBB is strong [25]. This suggests heterogeneous adsorption of both ions on the surface of MBB. The monolayer adsorption capacity for $\mathrm{Ni}(\mathrm{II})$ and $\mathrm{Cu}(\mathrm{II})$ ions was 7.25 and $6.95 \mathrm{mg} \mathrm{g}^{-1}$, respectively. The adsorption capacity for $\mathrm{Ni}(\mathrm{II})$ and $\mathrm{Cu}$ (II) by MBB is comparable with other reported adsorbents as shown in Table 3. 


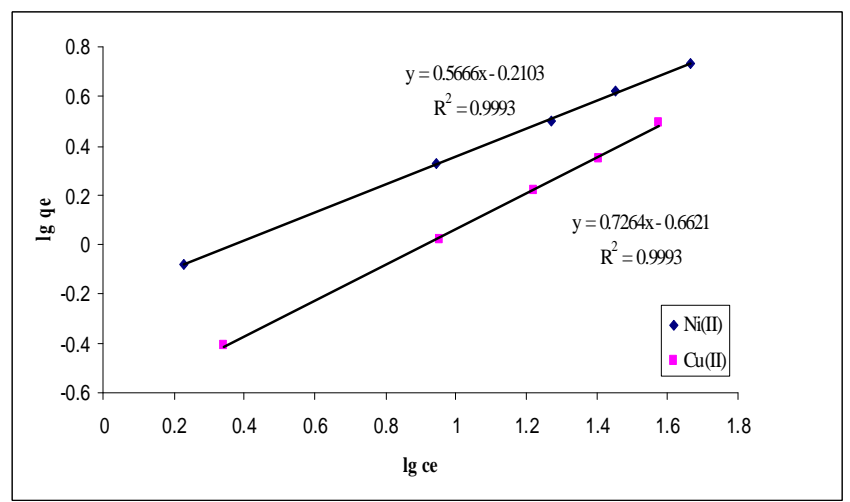

Fig. 5: Freundlich adsorption isotherms of $\mathrm{Ni}(\mathrm{II})$ and $\mathrm{Cu}(\mathrm{II})$ by MBB.

Table 2: Regression Parameters for the Adsorption Isotherms.

\begin{tabular}{clcc}
\hline Isotherms & & $\mathrm{Ni}(\mathrm{II})$ & $\mathrm{Cu}(\mathrm{II})$ \\
\hline \multirow{3}{*}{ Langmuir } & $\mathrm{q}_{\mathrm{m}}$ & 7.2098 & 5.8038 \\
& $\mathrm{~K}_{\mathrm{L}}$ & 0.1387 & 0.0271 \\
& $\mathrm{R}^{2}$ & 0.8759 & 0.9364 \\
\hline \multirow{3}{*}{ Freundlich } & $1 / \mathrm{n}$ & 0.5666 & 0.7264 \\
& $\mathrm{~K}_{\mathrm{F}}$ & 0.6162 & 0.2177 \\
& $\mathrm{R}^{2}$ & 0.9993 & 0.9993 \\
\hline
\end{tabular}

Table 3: Comparison of adsorption capacity of $\mathrm{Ni}(\mathrm{II})$ and $\mathrm{Cu}(\mathrm{II})$ ions with other adsorbents.

\begin{tabular}{|c|c|c|c|}
\hline Adsorbent & Solute & $Q \max$ & Reference \\
\hline $\begin{array}{l}\text { Activated carbon from } \\
\text { Hevea brasiliensis }\end{array}$ & $\mathrm{Ni}(\mathrm{II})$ & 16.892 & {$[26]$} \\
\hline $\begin{array}{l}\text { Black carrot (Daucus } \\
\text { carota L.) residues }\end{array}$ & $\mathrm{Ni}(\mathrm{II})$ & 5.745 & [27] \\
\hline $\begin{array}{l}\text { Chitosan/clinoptilolite } \\
\text { composite }\end{array}$ & $\mathrm{Ni}(\mathrm{II})$ & 7.940 & [28] \\
\hline Modified Mangrove Barks & $\mathrm{Si}(\mathrm{II})$ & 7.250 & This study \\
\hline Sawdust of deciduous trees & $\mathrm{s} \mathrm{Ni}(\mathrm{II})$ & 4.600 & [29] \\
\hline $\begin{array}{l}\text { Black carrot (Daucus } \\
\text { carota L.) residues }\end{array}$ & $\mathrm{Cu}(\mathrm{II})$ & 8.745 & {$[27]$} \\
\hline $\begin{array}{l}\text { Chitosan/clinoptilolite } \\
\text { composite }\end{array}$ & $\mathrm{Cu}(\mathrm{II})$ & 11.320 & [28] \\
\hline Modified Mangrove Barks & $\mathrm{S} \mathrm{Cu}(\mathrm{II})$ & 6.950 & This study \\
\hline $\begin{array}{l}\text { Mushroom (Agaricus } \\
\text { bisporus) }\end{array}$ & $\mathrm{Cu}(\mathrm{II})$ & 9.116 & [30] \\
\hline $\begin{array}{l}\text { Natural iron oxide-coated } \\
\text { sand }\end{array}$ & $\mathrm{Cu}(\mathrm{II})$ & 2.040 & [31] \\
\hline
\end{tabular}

\section{E. Adsorption Kinetics}

Kinetic studies were carried out under the optimized conditions from 0 to $180 \mathrm{~min}$. Fig. 6 shows that kinetic of adsorption initially increased rapidly and reach equilibrium within 60 minutes. There are three common step involved in adsorption process. The first step is mass transfer across the external boundary layer film of liquid surrounding the outside of the particle. Secondly is the adsorption process at individual site on the surface (internal or external) and the energy depends on the binding process (physical or chemical adsorption) this step is often assumed to be extremely rapid. Finally, diffusion of the adsorbate molecules to an adsorption site either by a pore diffusion process through the liquid filled pores or by a solid surface diffusion mechanism [32]. One or any combination of this adsorption process could be the rate-controlling mechanism.

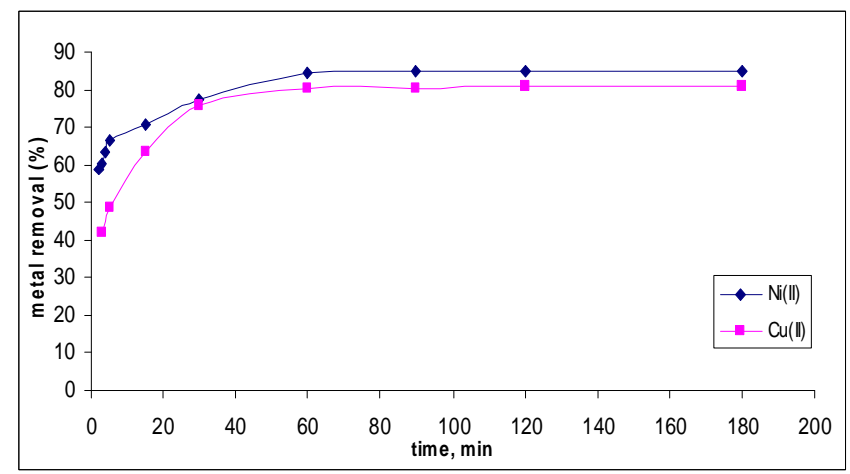

Fig. 6: Effect of contact time on the adsorption of $\mathrm{Ni}(\mathrm{II})$ and $\mathrm{Cu}(\mathrm{II})$ on $\mathrm{MBB}$.

The kinetic data obtained were fitted to linear form of pseudo-first-order and pseudo-second-order kinetic models. The pseudo-first-order kinetic model known as the Lagergen equation is expressed as:

$\log \left(q_{e}-q_{t}\right)=\log q_{e}-\frac{k_{1}}{2.303} t$

where $q_{t}$ and $q_{e}$ are the amounts of ion adsorbed at time $t$ and at equilibrium $\left(\mathrm{mg} \mathrm{g}^{-1}\right)$, respectively, and $k_{l}$ is the rate constant of pseudo-first-order adsorption process $\left(\mathrm{min}^{-1}\right)$. The slope and intercept of plots of $\log \left(q_{e}-q_{t}\right)$ versus $t$ were used to determine the first-order rate constant $k_{l}$ and equilibrium adsorption capacity $q_{e}$. Pseudo-first-order model is used to describe the reversibility of the equilibrium between liquid and solid phases.

The pseudo-second-order kinetic model is given as:

$$
\frac{t}{q_{t}}=\frac{1}{k_{2} q_{e}^{2}}+\frac{1}{q_{e}} t
$$

where $k_{2}$ is the equilibrium rate constant of pseudo-second-order adsorption $\left(\mathrm{g} \mathrm{mg}^{-1} \mathrm{~min}^{-1}\right)$. The plot of $t / q_{t}$ versus $t$ gives a linear relationship, and $k_{2}$ and $q_{e}$ can be calculated from the slope and intercept of the line (Fig. 7).

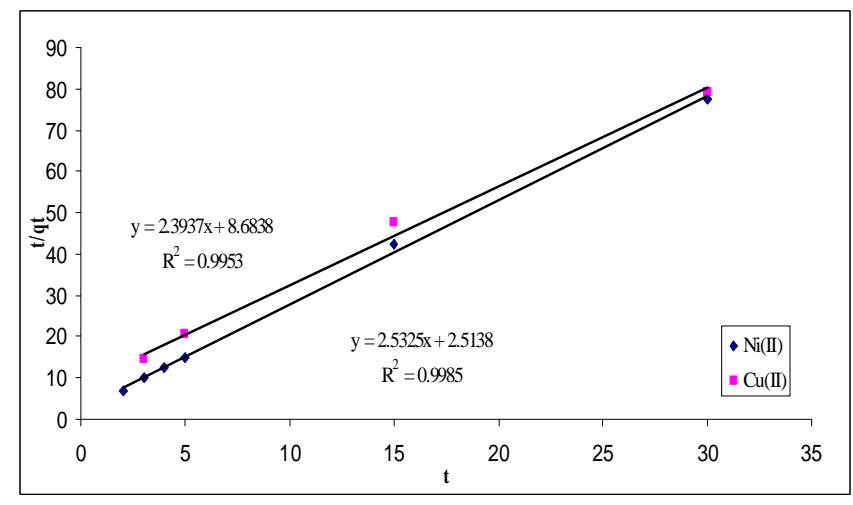

Fig 7: Pseudo-second-order plots of $\mathrm{Ni}(\mathrm{II})$ and $\mathrm{Cu}(\mathrm{II})$ adsorption onto MBB.

Result in Table 4 shows the kinetic rate constants, value of experimental $q_{e}$ and theoretical calculated $q_{e}$ for MBB. From the result, it can be concluded that pseudo-second-order equation provides the best correlation coefficient $\left(\mathrm{R}^{2}\right)$ and agreement between the calculated $q_{e}$ and the experimental $q_{e}$ values, suggesting that chemisorption is the rate-determining 
step in the adsorption of $\mathrm{Ni}(\mathrm{II})$ and $\mathrm{Cu}(\mathrm{II})$ ions on $\mathrm{MBB}$ [33].

Table 4: Regression Parameters for the Kinetics Models.

\begin{tabular}{llll}
\hline Kinetic model & & $\mathrm{Ni}(\mathrm{II})$ & $\mathrm{Cu}(\mathrm{II})$ \\
\hline q experimental & & 0.4212 & 0.4020 \\
\hline \multirow{3}{*}{ Pseudo-first- order } & $K_{1}$ & 0.0438 & 0.7715 \\
& $q_{e}$ & 0.1279 & 0.2459 \\
& $R^{2}$ & 0.9724 & 0.9941 \\
\hline \multirow{3}{*}{ Pseudo-second -order } & $K_{2}$ & 2.5513 & 0.6598 \\
& $q_{e}$ & 0.3949 & 0.4178 \\
& $R^{2}$ & 0.9985 & 0.9953 \\
\hline
\end{tabular}

\section{F. Thermodynamic Parameters of Adsorption}

In order to explain the effect of temperature on the adsorption of $\mathrm{Ni}(\mathrm{II})$ and $\mathrm{Cu}(\mathrm{II})$ ions on $\mathrm{MBB}$, thermodynamic parameters: standard Gibbs free energy $\left(\Delta G^{\circ}\right)$, standard enthalpy $\left(\Delta H^{\circ}\right)$, and standard entropy $\left(\Delta S^{\circ}\right)$ were determined. These parameters can be calculated from the following equations:

$$
\begin{aligned}
& \Delta G^{\circ}=-R T \ln b \\
& \ln b=\frac{\Delta S^{\circ}}{R}-\frac{\Delta H^{\circ}}{R T}
\end{aligned}
$$

where $R$ is the gas constant, $8.314 \times 10^{-3} \mathrm{~kJ} \mathrm{~mol}^{-1} \mathrm{~K}^{-1}, T$ is absolute temperature, $\mathrm{K}$, and $b$ is equilibrium constant at the temperature $T$, respectively. The values of $\Delta H^{\circ}$ and $\Delta S^{\circ}$ were obtained from the slope and intercept of the Van't Hoff plots of $\ln b$ versus $1 / T$ (Fig. 8). The negative value of $\Delta H^{\circ}$ indicates exothermic nature of adsorption which explains the decrease of $\mathrm{Ni}$ (II) and $\mathrm{Cu}$ (II) ions adsorption efficiency as the temperature increased. From the value of $\Delta H^{\circ}$, it is obvious that physisorption takes part in adsorption process in which the adsorbate adheres to the surface only through weak intermolecular interactions. Basically, the heats of chemisorption had higher activation energy of 40-120 kJ $\mathrm{mol}^{-1}$ when compared to energy of physisorption [34]. The negative values of $\Delta S^{\circ}$ indicate a decreased disorder at the solid/liquid interface during $\mathrm{Ni}(\mathrm{II})$ and $\mathrm{Cu}(\mathrm{II})$ ions adsorption. The negative value of $\Delta G^{\circ}$ (Table 5) indicates the spontaneity of the adsorption process which no external energy source is required for the system [35].

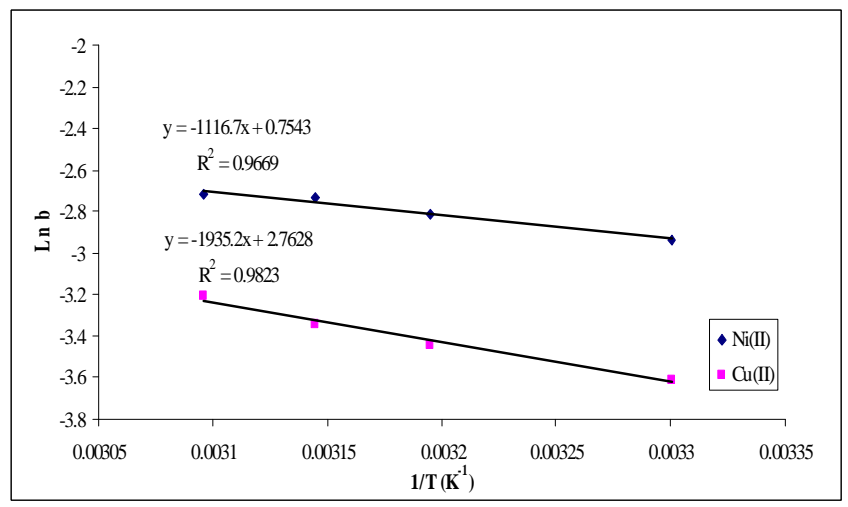

Fig. 8: Van't Hoff plot of adsorption of $\mathrm{Ni}(\mathrm{II})$ and $\mathrm{Cu}(\mathrm{II})$ onto MBB.

Table 5: Thermodynamic parameters of $\mathrm{Ni}(\mathrm{II})$ and $\mathrm{Cu}(\mathrm{II})$ adsorption by $\mathrm{MBB}$

\begin{tabular}{cccccc}
\hline Heavy & $T$ & \multirow{2}{*}{$\ln b$} & $\Delta G$ & $\Delta H$ & $\Delta S$ \\
metal & $(\mathrm{K})$ & & $\left(\mathrm{kJ} \mathrm{mol}^{-1}\right)$ & $(\mathrm{kJ}$ & $(\mathrm{kJ}$ \\
\hline
\end{tabular}

\begin{tabular}{cccccc}
\hline & & & & $\left.\mathrm{mol}^{-1}\right)$ & $\left.\mathrm{mol}^{-1} \mathrm{~K}^{-1}\right)$ \\
\hline \multirow{4}{*}{$\mathrm{Ni}(\mathrm{II})$} & 303 & -2.9353 & -7.2344 & & \\
& 313 & -2.8171 & -7.1722 & -9.2845 & 0.0063 \\
& 318 & -2.7318 & -7.2868 & & \\
& 323 & -2.7202 & -7.1774 & & \\
$\mathrm{~F}$ (II) & 303 & -3.6099 & -8.8972 & & \\
& 313 & -3.4394 & -8.7567 & -16.0896 & 0.0230 \\
& 318 & -3.3417 & -8.6440 & & \\
\hline
\end{tabular}

\section{CONCLUSION}

The ability of mangrove bark Rhizophora apiculata adsorbent for the removal of nickel and copper ions in simulated wastewater was investigated. The removal efficiencies clearly affected by the operation parameters. Equilibrium data was best found to fit Freundlich isotherm model indicating heterogeneous adsorption of $\mathrm{Ni}$ (II) and $\mathrm{Cu}$ (II) ions on the surface of bark adsorbents. Monolayer adsorption capacity of $\mathrm{MBB}$ for $\mathrm{Ni}$ (II) and $\mathrm{Cu}$ (II) ions was found as 7.25 and $6.95 \mathrm{mg} \mathrm{g}^{-1}$, respectively. The adsorption data was found to follow pseudo-second-order kinetic and reached equilibrium rapidly, within $60 \mathrm{~min}$ at $\mathrm{pH} 5$. Thermodynamics studies confirmed that the process was spontaneous and exothermic. The adsorption capacity is high despites the low surface area, indicating that the availability of the functional groups in the modified mangrove barks are more important than the surface area in this adsorption process. These findings suggest that MBB can exhibit as a potential adsorbent for the removal of $\mathrm{Ni}$ (II) and $\mathrm{Cu}$ (II) ions from aqueous solutions.

\section{ACKNOWLEDGMENT}

We acknowledge Ministry of Science, Technology and Innovation Malaysia (MOSTI) under grant (305/PKIMIA/613217), Universiti Sains Malaysia (USM) under grant (1001/PKIMIA/831019) and Fellowship scheme from Universiti Sains Malaysia for financial support of this work.

\section{REFERENCES}

[1] E. Denkhaus and K. Salnikow, Nickel essentiality, toxicity, and carcinogenicity, Critical Reviews in Oncology/Hematology 42(2002) 35-56.

[2] H. Tapiero, D. M. Townsend., K. D. Tew, Trace elements in human physiology and pathology: Copper, Biomedicine \& Pharmacotherapy 57 (2003) 386-398.

[3] I. Ghodbane, L. Nouri, O. Hamdaoui, M. Chiha, Kinetic and equilibrium study for the sorption of cadmium(II) ions from aqueous phase by eucalyptus bark, Journal of Hazardous Materials 152(2008) 148-158.

[4] C. M. Zvinowanda, J. O. Okonkwoa, M. M. Sekhula, N. M. Agyei, R. Sadiku, Application of maize tassel for the removal of $\mathrm{Pb}, \mathrm{Se}, \mathrm{Sr}, \mathrm{U}$ and $\mathrm{V}$ from borehole water contaminated with mine wastewater in the presence of alkaline metals, Journal of Hazardous Materials 164 (2009) 884-891.

[5] J. R. Memon, S. Q. Memon, M. I. Bhanger, A. Adel El-Turki, K. R. Hallam, G. C. Allen, Banana peel: A green and economical sorbent for the selective removal of $\mathrm{Cr}(\mathrm{VI})$ from industrial wastewater, Colloids and Surfaces B: Biointerfaces 70 (2009) 232-237.

[6] T. K. Naiya, P. Chowdhury, A. K. Bhattacharya, S. K. Das, Saw dust and neem bark as low-cost natural biosorbent for adsorptive removal of $\mathrm{Zn}$ (II) and $\mathrm{Cd}(\mathrm{II})$ ions from aqueous solutions, Chemical Engineering Journal 148 (2009) 68-79. 
[7] M. Šæiban, M. Klašnja, B. Škrbiæ, Adsorption of copper ions from water by modified agricultural by-products, Desalination 229 (2008) 170-180.

[8] F. Kaczala, M. Marques, W. Hogland, Lead and vanadium removal from a real industrial wastewater by gravitational settling/sedimentation and sorption onto Pinus sylvestris sawdust, Bioresource Technology 100 (2009) 235-243.

[9] D. Mohana and J. C .U. Pittman, Activated carbons and low cost adsorbents for remediation of tri- and hexavalent chromium from water, Journal of Hazardous Materials B137 (2006) 762-811.

[10] R. M. Rowell, Handbook of wood chemistry and wood composites, CRC Press, Florida, 2005, ch. 3.

[11] G. Vázquez, J. González-Álvarez, S. Freire, M. López-Lorenzo, G. Antorrena, Removal of cadmium and mercury ions from aqueous solution by sorption on treated Pinus pinaster bark: kinetics and isotherms, Bioresource Technology 82 (2002) 247-51.

[12] K. Swayampakula, V. M. Boddu, S. K. Nadavala, K. Abburi, Competitive adsorption of $\mathrm{Cu}$ (II), Co (II) and Ni (II) from their binary and tertiary aqueous solutions using chitosan-coated perlite beads as biosorbent, Journal of Hazardous Materials 170 (2009) 680-689.

[13] V. C. Taty-Costodes, H. Fauduet, C. P. Catherine, A Delacroix., Removal of $\mathrm{Cd}(\mathrm{II})$ and $\mathrm{Pb}(\mathrm{II})$ ions, from aqueous solutions, by adsorption onto sawdust of Pinus sylvestris, Journal of Hazardous Materials B105 (2003) 121-142.

[14] C. Longa, A. Li, H. Wub, Q. Zhanga, Adsorption of naphthalene onto macroporous and hypercrosslinked polymeric adsorbent: Effect of pore structure of adsorbents on thermodynamic and kinetic properties, Colloids and Surfaces A: Physicochem. Eng. Aspects 333 (2009) 150-155.

[15] W. S. Wan Ngah and M. A. K. M. Hanafiah, Adsorption of copper on rubber (Hevea brasiliensis) leaf powder: Kinetic, equilibrium and thermodynamic studies, Biochemical Engineering Journal 39 (2008) 521-530.

[16] M. Yurtsever and I. A. Şengil, Biosorption of $\mathrm{Pb}(\mathrm{II})$ ions by modified quebracho tannin resin, Journal of Hazardous Materials 163 (2009) 58-64.

[17] C. W. Oo, M. J. Kassim, A. Pizzi, Characterization and performance of Rhizophora apiculata mangrove polyflavonoid tannins in the adsorption of copper (II) and lead (II), Industrial Crops and Products 30 (2008) $152-161$.

[18] S. S. Zamil, S. Ahmad, M. H. Choi, J. Y. Park, S. C. Yoon, Correlating metal ionic characteristics with biosorption capacity of Staphylococcus saprophyticus BMSZ711 using QICAR model, Bioresource Technology 100 (2009) 1895-1902.

[19] F. Godea, E. D. Atalay, E. Pehlivan, Removal of Cr(VI) from Aqueous Solutions using Modified Red Pine Sawdust, Journal of Hazardous Materials 152 (2008) 1201-1207.

[20] T. A. Kurniawan, G. Y. S. Chan, W. H. Lo, S. Babel, Comparisons of low-cost adsorbents for treating wastewaters laden with heavy metals, Journal Science of the Total Environment 366 (2006) 409- 426.

[21] M. Rafatullah, O. Sulaiman, R. Hashim, A. Ahmad, Adsorption of copper (II), chromium (III), nickel (II) and lead (II) ions from aqueous solutions by meranti sawdust, Journal of Hazardous Materials 170 (2009) 969-977.

[22] J. Kassim, K.Y. Lan, R.C. Amat, Mangrove Bark - a Potential Biomass Adsorbent for Removal of Basic Dye from Aqueous Solution, International Journal of Chemical Engineering 1 (2008) 321-336.

[23] S. Liang, X. Guo, N. Feng, Q. Tian, Isotherms, kinetics and thermodynamic studies of adsorption of $\mathrm{Cu}^{2+}$ from aqueous solutions by $\mathrm{Mg}^{2+} / \mathrm{K}^{+}$type orange peel adsorbents, Journal of Hazardous Materials 174 (2010) 756-762.

[24] Z. Aksu and G. Dönmez, Binary biosorption of cadmium(II) and nickel(II) onto dried Chlorella vulgaris: Co-ion effect on mono-component isotherm parameters, Process Biochemistry 41 (2006) 860-868.

[25] V. O. Arief, K. Trilestari, J. Sunarso, N. Indraswati, S. Ismadji, Recen Progress on Biosorption of Heavy Metals from Liquids Using Low Cost Biosorbents: Characterization, Biosorption Parameters and Mechanism Studies, Clean 36 (12) (2008) 937 - 962.

[26] H. Kalavathy, B. Karthik, L. R. Miranda, Removal and recovery of Ni and $\mathrm{Zn}$ from aqueous solution using activated carbon from Hevea brasiliensis: Batch and column studies, Colloids and Surfaces B: Biointerfaces 78 (2010) 291-302.

[27] F. Güzel , H. Yakut, G. Topal, Determination of kinetic and equilibrium parameters of the batch adsorption of $\mathrm{Mn}(\mathrm{II}), \mathrm{Co}(\mathrm{II}), \mathrm{Ni}(\mathrm{II})$ and $\mathrm{Cu}(\mathrm{II})$ from aqueous solution by black carrot (Daucus carota L.) residues, Journal of Hazardous Materials 153 (2008) 1275-1287.

[28] M. V. Dinu and E. S. Dragan, Evaluation of $\mathrm{Cu} 2+, \mathrm{Co} 2+$ and $\mathrm{Ni} 2+$ ions removal from aqueous solution using a novel chitosan/clinoptilolite composite: Kinetics and isotherms, Chemical Engineering Journal 160 (2010) 157-163.
[29] D. Bǒzić, V. Stanković, M. Gorgievski, G. Bogdanović, R. Kovačević, Adsorption of heavy metal ions by sawdust of deciduous trees, Journal of Hazardous Materials 171 (2009) 684-692.

[30] N. Ertugay and Y.K. Bayhan, The removal of copper (II) ion by using mushroom biomass (Agaricus bisporus) and kinetic modeling, Desalination 255 (2010) 137-142.

[31] N. Boujelben, J. Bouzid, Z. Elouear, Adsorption of nickel and copper onto natural iron oxide-coated sand from aqueous solutions: Study in single and binary systems, Journal of Hazardous Materials 163(2009) 376-382.

[32] W. H. Cheung, Y. S. Szeto, G. McKay. Intraparticle diffusion processes during acid dye adsorption onto chitosan, Bioresource Technology 98 (2007) 2897-2904.

[33] L. Guo, C. M. Sun, G. Y. Li, C. P. Liu, C. N. Ji, Thermodynamics and kinetics of $\mathrm{Zn}$ (II) adsorption on crosslinked starch phosphates, Journal of Hazardous Materials 161 (2009) 510-515.

[34] M. Alkan, Ö. Demirbaş, S. Çelikçapa, M. Doğan, Sorption of acid red 57 from aqueous solution onto sepiolite, Journal of Hazardous Materials B116 (2004)135-145.

[35] A. Hawari, Z. Rawajfih, N. Nsour, Equilibrium and thermodynamic analysis of zinc ions adsorption by olive oil mill solid residues, Journal of Hazardous Materials 168 (2009) 1284-1289. 